[Greenwood, J., Mayo, E., Hārata Te Aika, L., \& Walker, L. (2007). Merger, Mana, Scholarship and Power: Four Perspectives of Issues Impacting on Quality in Teacher Education in the Merger of College of Education with University. New Zealand Annual Review of Education, 16, 5-28]

\section{Merger, Mana, Scholarship and Power: Four Perspectives of Issues Impacting on Quality in Teacher Education in the Merger of College of Education with University}

\section{JANINKA GREENWOOD, ELAINE MAYO, LYNNE HĀRATA TE AIKA, AND LAWRENCE WALKER}

\section{Abstract:}

The merger of the Christchurch College of Education with the University of Canterbury on January 1, 2007 was the pivotal point of major change for academic staff in the College, and focused a number of areas of contested values. This article is a collection of four narratives of that change, each examining a particular issue. Each of the narratives tells the story of a particular struggle to preserve an aspect of the overall quality of teacher education, and also foreshadows an ongoing philosophical and political engagement in the years that will follow the merger. The weaving of the four narratives seeks to capture a sense of the multiplicity of professional concerns that are experienced by professional educators and that are contested in the process of merger. This article comes from the perspective of academic staff from the former College of Education, and in its use of personal voices reflects the lived experience of wrestling with change and sometimes perceived threat. However, it has implications for other merged colleges of education, and for teacher education as a whole.

\section{The Context: Merger}

On January 1, 2007 the Christchurch College of Education merged with the University of Canterbury. Together with the Dunedin College of Education, it was the last of the distinct, public sector teacher education institutions to lose its independence. The merger completed the movement over the last

\section{Janinka Greenwood et al.}

two decades of teacher education into the universities.

As recently as 2004 the College Council appointed a new Principal to what they heralded as an institution that would continue to stand alone and aspire to an academic excellence that was professionally and experientially based. At that time there were still four stand-alone Colleges of Education in each of the cities of Auckland, Wellington, Christchurch and Dunedin, although Wellington and Auckland were considering merger. It would be an interesting field for future writings to explore the various complex imperatives for mergers and the key reasons for resistance. Here, at the risk of simplification, the debate might be summed up as: an advocacy for teacher education to be placed within a university context because it would facilitate research-based courses, align with other professional disciplines such as law and medicine, and align with practices overseas; and a defence of the particular inductive nature of teacher education and the need to preserve its relationship and service to the community of schools.

By the time Christchurch came to consider merger it was no longer an open choice. Incremental shortfalls in government funding (Alcorn, 2002), as well as ministerial statements, made the financial and political prospects of independence unattractive and perhaps untenable. Moreover, once the national platform for teacher education had moved to the universities, it was questionable whether the interests of the South Island could be met by a system different from the rest of the country. So at the beginning of 2005 the merger and the changes that would arise from it were inevitable.

This article was written in the weeks immediately before and after the merger. As writers we focus on our professional concerns. We are aware that in the time following the merger there are other new and important issues to examine as the merged enterprise grows, but they are not the subject of this paper. Perhaps they will be of a future one.

\section{A Collaborative Project: The Four Strands of this Paper}

Our branch of our academic staff union, the Association of Staff in Tertiary Education (ASTE), accepted change. The challenge for us was to decide which aspects of change we needed to fight, which to facilitate and which simply to survive. We conceptualised our project in terms of an action research study, with overlapping projects and spin-off cycles. The overarching union issue was to ensure academic staff voices were consulted, heard and protected. Groups within the staff brought other concerns, such as: 
- How can we maintain the mentoring aspect of teacher education?

- How can we retain the Māori initiatives we have developed?

- How can we develop practitioner research?

- How can we achieve equity in pay and conditions?

- How can our work be recognised in terms of national research expectations?

This article reports four of the issues that took our attention in the two years leading up to the merger. Each offers an insight into the way the academic staff grappled with change and each represents an important element of the quality of teacher education that we sought to preserve. Each has continuing policy and practice implications, and continues as a significant struggle beyond the moment of merger.

First, Elaine Mayo points to the importance of metaphor and theory in praxis and suggests that the merger process can be seen as an example of collaborative research in practice. Secondly, Lawrence Walker, from the position of Branch Chair, gives a narrative account of key elements of ASTE's industrial and professional engagement. Next, Lynne Hārata Te Aika describes the struggle to retain a robust Māori presence, referencing her work from Māori knowledge as well as that of the academy, and following Māori expectations of scholarship, honours the processes of the heart as well as of the head. Finally, Janinka Greenwood, drawing on her personal practice, examines the scholarship of teaching and advocates its value within considerations of research and its reportable products.

\section{Metaphors of Merger: Seeking Ongoing Conversations (Elaine Mayo)}

In 2005, when both ASTE and the staff representatives on Academic Board protested at the lack of academic staff representation on the management-dominated merger planning groups, I joined the Academic Planning Group for the merger as Academic Board representative. My challenges were to voice staff concerns and promote ideas that were not yet clearly formulated. The union, with its commitment to professional as well as industrial issues, provided a necessary forum for discussion. In this section I write about the philosophies, experiences and insights that guided my work and provide a theoretical basis for my underpinning argument that knowledge emerges in praxis.
This is the story of the emergence of new knowledge, by which I mean new ways of being, understanding, creating our futures. Theideas described in this section underpinned my work in ASTE. My understanding of the importance of metaphor and emergent knowledge motivated me to try, at all costs, keep the conversations going within and among the various interest groups involved in the merger. I begin by pointing to metaphors of merger, before discussing theoretical and then practical interpretations of ASTE's praxis. My thesis is that the New University has the potential to serve teaching and teacher education very well, even in the era of the Performance-Based Research Fund (PBRF), provided it fosters synthetic forms of research that are accessible to teachers.

\section{Metaphors of merger}

Metaphor has a powerful effect on action (Lakoff \& Johnson, 1980). Instead of the metaphors of "take over", "submersion" or "romantic union and marriage" that have at various times guided different aspects of our thinking and action, I see the praxis of ASTE over the last two years as being better explained using three further metaphors. The merger as "cauldron" considers not the institution but the ideas that are under discussion. It highlights the need for ideas that are deemed to be important to be spoken about and brought to the surface in discussions with influential decision makers, so that grassroots ideas are not overlooked. The merger as "creation of a new university" foresees the influence the University College of Education will have because it will be one fifth of the whole. For this metaphor to be effective, the academic status of teacher education needs to be established. The third metaphor of is that of complex emergence where fresh insights and practices (i.e., fresh knowledge and structure) are generated through "ongoing conversations" (Mayo, 2003). This metaphor signals the paradigm change from the decision-making structures of an industrial age to those of an information age where "bottom-up intelligence" replaces hierarchical decision making (Johnson, 2001).

\section{Theoretical Influences: Toward Understanding Complex Change}

When I am hurting I turn to theory. (hooks, 1994)

As I see it, Janinka Greenwood's discussion, in the final section of this paper, of how teachers call on various forms of knowledge in praxis could be seen as a spin on Schön's (1983) reflection-in-practice and an affirmation of the importance of synthetic, as opposed to analytic, 
thinking in teaching (Lechte, 1994). The challenge for the teacher education community is to find ways to foster synthetic praxis in the merged academy. In this section I look to postmodern and complexity theory to find justification for forms of research that are synthetic, emergent, and which generate forms of knowledge that recognise the importance of relationships within communities of educational practice.

\section{Post-structural theory}

Post-structural theory challenges the assumption that there is a single best explanation for any event, or a single best set of values or beliefs; all knowledge is contextual even though some forms of knowledge are well established and have great explanatory power (Gilbert, 2005).

Several aspects of post-modern theory are particularly relevant. First is the logic of both/and rather than either/or (Burr, 1995, p. 107): rather than selecting the better of two propositions (synthetic and analytic thinking, for example), it is more useful to consider the impact of using various propositions and to choose among them in the situation. Second is the shift in understanding the nature of knowledge. Knowledge is unruly (Stronach \& MacLure, 1997, p. 98), and becomes the ability to act effectively (Kvale, 1996, p. 19). Third is the notion that we can usefully think of ourselves not as separate discrete individuals but as praxis-oriented selves (Schrag, 1997) who are defined by the things we say and do as parts of larger, self-organising social structures. These ideas allow fresh social understandings to emerge through research into praxis.

\section{Complexity theory: Emergence and self-organising systems}

Complexity theory not only allows synthetic (non-linear) thinking and fresh approaches to understanding, it recognises that to avoid such approaches may be positively dangerous. This is because "[n]o single person or school of thought has the answer, because what's required is far beyond isolated answers" (Wheatley 1999, p. 173) and because "wicked" social problems are never solved: "At best they are only resolved - over and over again." (Skyttner, 1996, p. 248)

The cauldron metaphor is supported by complexity theory's notions of "bottom-up intelligence" (Johnson, 2001), the "emergence of order from disorder, lawfulness from chance, structure from chaos" (Rescher, 1998, p. 206). The intelligence of a collective is dependent on the emerging insights of the participants; these emerging insights are, in turn, influenced by the growth of shared understandings. New knowledge emerges, bottom-up, in context. Understandings of the complex whole are lost if we focus only on component parts (Davis et al., 2000).

Complexity theory explains how the accumulation of the praxis of individuals and groups in society is (r)evolutionary social change. In dealing with large scale social problems we need to move beyond the isolated disciplines of the academy and grapple with messy, ongoing problems where relationships among people matter (Helgesen, 1996).

\section{Complexity theory impacts on education}

Many theorists highlight the idea of moving beyond the analysis of individual components of a system toward consideration of the complexity of the whole. Garmston \& Wellman, for example, call attention to the way "schools are complex dynamical systems that are continually influenced by many variables." Like weather systems "the course of school improvement" is "unpredictable in [its] details but not in [its] patterns" (1999, p. 2). Similarly, Davis et al. (2000) call on complexity theory to distinguish emergent, constructivist and ecological theories of learning, from those that are more mechanistic. I argue (Mayo, 2003, 2005) that these kinds of ideas point to the need to foster an understanding of collective praxis and to wonder how, in teacher education, we might begin to report our collective learning as research.

\section{Emergent Methodologies}

The notion that ideas can emerge, bottom-up, through the lived experiences of teachers both surfaced during, and was used to inform, an empirical investigation from the Ministry of Education's Early Childhood Education Centres of Innovation project (ECE COI) ${ }^{1}$. This work, described in Wright, Ryder and Mayo (2006) involved participants in various interrelated research-oriented conversations. The teachers and their research associate came to recognise that the assessment tool used in ECE settings, the learning story (see Carr, 2001), could be used to report the learning that was emerging for them. They wrote three kinds of learning stories: about the children's learning, about their own learning as teachers, and about their learning to do with research and researching. These learning stories contributed to three ongoing sites of conversation where adults and children shared their emerging ideas, tested out their current theories, and explored fresh ideas. The learning stories could be quite short, quite deep, quite challenging, but all were data. All were documented and available as resources for ongoing, critically-reflective conversations. 
We have since come to recognise that another, more methodological conversation has surfaced. The notion of learning stories might point to some kind of emergent methodology which embodies new narrative ways of recording the complexity of educational experiences. Such a methodology would, for example, allow snippets of emerging ideas to be explored collectively, in a community of practice where varied voices are heard. Schalager and Fusco explain that "a community of practice is not just another term used to convey a sense of professional kinship or shared interest; it is an integral, evolving identity that spans stakeholder groups within a school system (Schalager \& Fusco, 2002, p. 217).

\section{Collective research and the individual voice}

In the light of the above, Figure 1 represents a way of understanding the ongoing conversations where stories about emerging insights would inform teacher educators and researchers. Each column represents a central theme or interest, while the rows show how ideas from one ongoing conversation would inevitably inform those in other columns.

\begin{tabular}{|c|c|c|c|}
\hline $\begin{array}{c}\text { Conversations } \\
\text { about } \\
\text { learning }\end{array}$ & $\begin{array}{c}\text { Conversations } \\
\text { about } \\
\text { teaching }\end{array}$ & $\begin{array}{c}\text { Conversations } \\
\text { about } \\
\text { researching }\end{array}$ & $\begin{array}{c}\text { Conversations } \\
\text { about } \\
\text { methodology }\end{array}$ \\
\hline \multicolumn{4}{|c|}{ Learnership responsibilities } \\
\hline Students & Students & & \\
\hline \multirow[t]{3}{*}{$\begin{array}{l}\text { Teachers/ } \\
\text { Educators }\end{array}$} & $\begin{array}{l}\text { Teachers/ } \\
\text { Educators }\end{array}$ & $\begin{array}{l}\text { Teachers/ } \\
\text { Educators }\end{array}$ & \\
\hline & $\begin{array}{l}\text { Praxis-based } \\
\text { researchers }\end{array}$ & $\begin{array}{l}\text { Praxis-based } \\
\text { researchers }\end{array}$ & $\begin{array}{l}\text { Praxis-based } \\
\text { researchers }\end{array}$ \\
\hline & & Methodologists & Methodologists \\
\hline
\end{tabular}

Each kind of conversation involves various people in various roles (students, teachers/educators, praxis-based researchers, and those who theorise about research methodology) in conversations where they have responsibility for learning (learnership responsibilities).

Figure 1 Four kinds of conversation within a tertiary education environment
The notion of "learnership responsibility" points to the idea that all participants in any conversation are constantly learning and adapting their thinking on the basis of their experience. Where patterns emerge within these complex cauldrons of ideas, then these need to be recorded. Such recordings are the work of individuals whose publications can then be peer reviewed within the community and beyond.

Assuming that PBRF-rated research requires publication and discussion within a critical community of praxis, Figure 1 now suggests that each kind of conversation might generate PBRF outputs. The notion of the learning story as the unit of analysis within such conversations has the potential to enable the insights of various participants to inform the work of other groups.

The energy required of staff during a merger reduces the energy available for producing research outcomes. As for the teacher in the classroom, the day-to-day life of the academic involved in institutional merger leaves little time for reflective, academic writing. Yet, as this section illustrates, collaborative approaches to knowledge construction can generate insights into the praxis of merger and so of themselves constitute useful research.

\section{Asserting the Voice of Academic Staff (Lawrence Walker)}

\section{A regional tradition of collaboration}

In the first instance the challenge of the merger was a political one: how could we ensure academic staff concerns would be heard and addressed in a process that was driven by national politics and the two institutions' powerholders? The rhetoric of advocacy repeatedly conceptualised the merger as an academic marriage (e.g., Sharp, 2007). The College came with a small but significant dowry of EFTS, campus site, niche market, experienced staff and operational programmes. The university offered the husbandly protection of size, stability and research reputation. How could the academic staff ensure that the marriage not only led to a stronger entity but also protected the work and status of the bride as well as the groom? The issue is one that remains central in these first years after the merger.

ASTE was able to enter the play with some advantages as well as sizeable challenges. One advantage was a commitment to tertiary collaboration that had been established in Canterbury (Canterbury 
Tertiary Alliance). The reforms of the 1980s (Thrupp, 1999) had opened the tertiary sector to extensive inter-institutional competition and some did develop in Canterbury. The College of Education entered the Polytechnic's formerly exclusive territory and launched what grew into a very successful School of Business (Fletcher, 2006). The Polytechnic retaliated with a programme in initial primary teacher education. A local private provider also entered the field with initial teacher education programmes for graduates. However, unlike others in the country, the University of Canterbury did not develop its own teacher education programmes. Instead several conjoint degrees were developed, with College and University delivering component parts. Later, in the spirit of the Alliance, the Polytechnic discontinued its teacher education programme. Thus a practice of collaboration had already developed in terms of programmes.

However, if programmes were not an initial source of problems, differences in culture were. Cameron and Gilbert (2002) identify different premises on which courses are built in universities and colleges respectively. Universities stress the role of academic freedom, the potential of the discipline, the paramount importance of research. Colleges stress knowledge that is useful in school settings, the production of classroom-ready graduates and the modelling of collaboration and other useful school processes. The threat, as ASTE perceived it, was that University staff looked at their College colleagues as junior in terms of academic scholarship, and we feared that the merger would undermine the flexibility of the College and its responsiveness to local needs.

\section{Industrial activism}

ASTE entered the pre-merger debates with a sense of playing David to the University's Goliath, but it did hold a strong card in terms of the density of the branch membership. Over eighty percent of College academic staff are union members. There had been a history of consultation, and when possible collaboration, between management and union on a wide range of issues. The practice of co-operation was formalised in a number of terms in the collective agreement. However, the mechanics of merger preparation took place in committees and working parties that were not addressed in that agreement. The union had to actively strategise to have a voice in these.

We had regular indicators that our power to influence was limited. Decisions were made about processes, into which we had no input. Nor did we have ready ways of addressing underlying assumptions. Above all we initially had no way to negotiate directly with the powerbrokers in the university.

The first strategies we used are fundamental to union activism. They involved insistence on regular consultation by our CEO and the merger project manager about the progressive details of the merger process, insistence on representation in working parties, lobbying of Council members, regular presentation of submissions, and collaboration with all the other unions involved. Our "insistence" was backed by the solidarity of our members and their willingness to take direct action, and the potential opportunity of going to the media. Both threats were powerful incentives for management to include our voice. But both also had the power to impact negatively on enrolments and harm our members, and so were weapons that needed to be carefully used.

\section{Developing participatory processes}

Along with the mobilisation of our members politically, we also provided opportunities for them to engage in discussion about all the issues they saw as relevant to the merger and about the parts of their work that they feared might be under threat. Among these were the concept of developing classroom readiness, the relative progress the College had made in bicultural perspectives, the delivery of our regional and flexible learning programmes, the terms of the Teacher Education Manifesto (ASTE, 2005), the tension between the existing structures based on early years, primary and secondary sectors and the proposed new grouping into subject-based schools. These discussions took place on-line and in Friday afternoon fora, and the issues raised were written on display boards and glass partitions for all staff to read and add to.

Many of the points raised made their way into the discussions and decisions of the various working parties, as illustrated by Elaine Mayo's previous contribution. Perhaps even more importantly, they raised the collective consciousness of academic staff, and they allowed us to use the merger to further our exploration of the professional issues that were important to us. Two of those explorations follow.

\section{Challenging processes and assumptions}

One specific challenge was the process of mini-mergers by which various service sectors of the College, such as the library, were merged in advance of the academic merger. As a union we had no automatic right of input into decisions that impacted on members of another 
union, but the transfer proposal disestablished all jobs and required all staff to apply for the new ones. That constituted an unacceptable precedent. We stated our strong and unequivocal opposition and our intention to challenge the proceedings legally. For a time relations with management reached a significant low, but the proposal was amended. We learned the importance of challenging the first of incremental assaults on conditions of service.

The issue of the terms and conditions by which academic staff would be transferred to the University was a fundamental one and drawn-out in its resolution. Soon after the confrontation discussed above, we were given a firm assurance that all tenured academic staff would be carried through to the university on parallel salary levels. What was not offered was recognition of service or of current status. We used the processes of union collectivism to make ourselves heard and we were able to negotiate directly with the University decision-makers. We also collected our own data, preparing clear graphic presentations, and we synthesised the arguments about the scholarship of teaching and practitioner research that had arisen in the Friday sessions. It was clear that while finance was an important factor, so were the embedded, and perhaps unprocessed, assumptions made by the managers of the merger. We were partially successful in winning our case. Full recognition of service was given and so was access to all university conditions. Academic staff kept their titles, though they transferred on existing salaries. We were not successful in claiming Associate Professor status for our Principal Lecturers, but we did win the right for them to seek that promotion immediately in the 2006 University round. Only a couple won the promotion but their success affirmed the scholarliness of our academic staff and the University's recognition of their value.

Our greatest learning in the process leading up to the merger was that while we were overtly less powerful, power operates in a dynamic tension, and we could utilise that tension to protect the conditions of our members. We needed to sustain our commitment to collaboration at the same time as we maintained our potential to disrupt, and our capacity to bring new insights to the table. Feedback at the end of 2006 suggests that those who managed the merger saw similar usefulness in the tension. Perhaps that is an initial basis for negotiating a relationship. The challenge for us now is to continue to develop the relationship in order to address current problems, particularly the impact of workload on time to engage in research, so as to qualify for promotion in terms which are compatible with the overall goals of teacher education.
3. M Wai R E Hoe Te Waka Nei? Impact of the Merger on M ori (Lynne Hārata Te Aika)

Even without a physical move, the migration of people from one academic tertiary institution to another requires a transformation of mind, spirit and puku (gut). From the perspective of a Māori academic leader in the College I share how the merger and its attendant restructurings have impacted on Māori. What we have experienced will, I believe, find parallels in the experience of indigenous peoples around the world who are minority groups within their countries' tertiary institutions, and whose interests are, often unconsciously, compromised as different academic and economic pressures compete for priority.

The historic scholarly tradition for Māori, along with many other indigenous cultures, is the oral tradition (Royal, 1990). Events from the past are recalled to help shape and determine responses to present and future events. The lessons and values learned historically are used to address contemporary issues and challenges. To capture a sense of this tradition, which is still relatively new in academic contexts in Aotearoa, I use metaphors of waves and waka (canoe), and relevant Māori whakatauki or proverbs.

Māori tradition tells us that Māori were great voyagers who travelled the Pacific ocean, using the stars for navigation. They journeyed from island to island, making several return trips. When they discovered new land, whether through accidental or purposeful voyaging, and settled into that place there was often a waka oral tradition associated with arriving at the new destination. Often some kind of calamity would occur where the people in the waka or the waka itself was placed at risk. This event was part of the migration story and of the claiming and settling of the new island home. In Ngāi Tahu traditions there were several waka that brought people to Te Waipounamu. The Aoraki waka capsized and turned into mountains and rock, or the Southern Alps. The Arai-te-uru waka landed near Moeraki where the bow of the waka struck a rock and the waka capsized. The gourds carrying food turned into stone and became the Moeraki boulders. There is also the story of the Takitimu waka that circumnavigated the island and capsized in southern Fiordland and turned into the Takitimu mountain ranges (Tau, 2004; Evison, 2005; Anderson, 2005). I will liken the journey that Māori staff in our institution have taken through financial restructuring and merger to that of a waka tradition. 
$\mathrm{T}$ ngaru, $\mathrm{t}$ aha, ka $\mathrm{r}$ naki te haere: $\mathrm{M}$ ori and bicultural initiatives 2001-2004.

Without waves, without obstruction the canoe will glide on. The progress of the organisation will go smoothly. (Mead E Grove, 2001: 2381)

The Christchurch College of Education had developed a number of initiatives for Māori. A Māori senior management position was established in 2001. A strategic plan was developed (Te Aika, Greenwood \& Brown, 2003) to implement Māori and bicultural outputs for staff and students. Numbers of Māori staff in the institution tripled and the number of strategic outputs for Māori increased, with tangible outcomes for local iwi. A bilingual teacher's course was established. Course content across selected curriculum areas was enhanced. A Treaty education programme for staff and students was developed and implemented. It was a period of growth and expansion for Māori.

The future promised a smooth passage with the sea spread out like polished greenstone: ka whakapapa pounamu te moana, ka tere te kārohirohi. (Mead \& Grove, 2001: 1205)

\section{Kore te hoe, kore he tat : Financial restructuring 2005-2006}

No paddle; no baler. A canoe at sea in such a hopeless situation was sure to be lost. This expression was applied to a tribe hemmed in by enemies with no way out. (Mead E Grove, 2001: 1488)

In December 2005, Māori academic and general staff numbered 41 EFTS. By February 2006, that number was reduced by thirty-three per cent, as Māori staff took redundancy (voluntary and forced) through the College's cutbacks. The insecurity created by financial restructuring meant it was difficult to see a way forward. Some of our Māori staff didn't have the energy to keep up with the fight, or they could see more unhappy times ahead, so they decided to leave.

Although many of the redundancies were voluntary, the impact was marginalisation of Māori staff, Māori students, and of te reo and tikanga Māori as teaching subjects. There were fewer staff to share the workload. Students who had previously enjoyed a high level of support felt somewhat abandoned. It can be likened to navigating unchartered waters, experiencing choppy and turbulent times, seasickness, abandonment of the waka. In a very short space of time Māori staff, along with other staff, had moved from a warm tropical destination to turbulent chaos in a cold and unfriendly environment, with the fear the waka was about to capsize.
Kaua e rangiruatia te $h$ pai o te hoe: e kore $t$ tou waka $e$ ki uta: input into the merger

Do not lift the paddle out of unison or our canoe will never reach the shore! (Mead \& Grove, 2001: 1180)

This whakataukī emphasises the importance of working together to succeed in any joint project and it focused our input into the Merger Business Case. The Case acknowledged the imperative to "transfer the strong Māori and Bicultural commitment that exists within the current CCE to the new UC College of Education", and noted the risk of possible "loss of ... an improving CCE Māori staff and student profile and programme development" (University of Canterbury, 2005, p. 3).

In Màori oral tradition it was common to associate changes in the physical environment to signs of change in a culture. In November, 2006 there was an unprecedented appearance of icebergs off the East Coast of the South Island. From a Māori perspective they could be seen to signify a number of events impacting on language, culture and society. They offer a physical analogy to the stress and erosion of wairua that impacted on staff at the College. After twenty four months of constant and targeted financial reforms, staff became unsettled and less collaborative. More alarming was the impact on the physical and mental well-being of staff, coupled with the declining mana and status of our language and culture. The two years could be described as te wā o te Pōhara, a period of cultural poverty and depression. We had diminished human and financial resources. In turn our students suffered. We had Māori staff who were non-specialist teachers of te reo suddenly picking up a high teaching load for te reo and tikanga Māori. It didn't happen in any other subject area. Because we had lost several Māori lecturers from Primary teacher education our whānau programmes became almost non-existent as temporary relief staff were bought in to plug gaps. More of us asked ourselves: me noho tonu ahau, me haere ranei? Should I stay or should I go?

He ora te whakapiri, he mate te whakat kiri : The new University of Canterbury College of Education

Survival comes by sticking together, disaster by separation. (Mead \& Grove, 2001: 607)

Post-merger planning for the new College of Education has began. Discussion about the proposed College and the four new schools brought isolated Māori together and united us. Most of the Māori staff, 
who have survived the turbulent two years, the morehu, will be part of the new School of Māori, Social and Cultural Studies which brings Māori across Early years, Primary and Secondary levels together. There is some hope that a new structure will rebuild Māori unity and develop learning and teaching programmes for Māori.

We have left the rapids and choppy sea of our migration story. We are refloating the waka. We are reaching the entry to the harbour where we will drop anchor and claim our new island home. The journey has been rough and there have been many casualties, but there is a calming as the new structure starts to unfold - a calm after the storm.

The new home, however, is different from the one we have previously known. It has a different climate, and we Māori are slightly out of our comfort zone. There are new systems and values to adapt to and PBRF and research output expectations.

\section{He toa turanga rau, he toa kaipaoi}

The whakatauki tells us that expert food providers had many stopping places. It was traditional for a tribal group to move from one campsite to another in an effort to obtain adequate subsistence. (Mead and Grove, 2001: 771)

Those of us who transfer to the new College have done so out of need for employment rather than desire to work in a University environment. The final impact of the merger is yet another story. However, we need to berth the waka, claim a new campsite and make the University a permanent and sustaining home. As Castello (2000) reminds us, "the dynamic nature of indigenous knowledge, traditional knowledge will assume new forms of expression as it is applied to contemporary social and environmental challenges". So we resolve to be strong and row in unison. Nā reira, kia kaha kia kotahi te hoe o te waka.

\section{An Examination of the Complex Scholarships of Teaching (Janinka Greenwood)}

Initial motivation for asserting the scholarship of teaching was to gain recognition for the experience and expertise of academic staff in the College. As I engaged in the ASTE project I began to explore in more detail the complexity of the knowledges that underlie the everyday process of teaching. Later a working definition of the concept developed (Greenwood, 2005, Greenwood \& Walker, 2006).

The scholarship of teaching consists of the complex clusters of knowledges and strategies that teachers draw on. Some are drawn on consciously; others are sub-conscious. Each teacher has his or her personal repertoire. But there is also a significant body of collective knowledge, of which there are some written accounts, but much is passed on through interpersonal interactions. The ability to draw on and select effective strategies from this body of knowledge involves a form of artistry.

In this way I use the term with a slightly different emphasis from that used by others (for example Trigwell, Martin, Benjamin, \& Prosser, 2000; Boyer, 1990) who are concerned about discriminating levels of scholarship within teaching. I am more concerned with capturing the comprehensive nature of the scholarship and its complexity.

First I offer, as illustration, an analysis of two of my own teaching moments that took place in a community drama project at Takou Bay (Greenwood, 2006). Then I discuss the strategic importance of recognising this scholarship.

\section{It looks so simple, but in the background...}

In the Takou Bay project I was invited to lead a marae-based drama summer workshop. The workshop had a twofold intention: to build a performance around a local history and to strengthen learning bonds between young people and their wider family groups. There were about twenty young people involved, ranging from four- to fifteen-year olds. The history the elders had selected for our work was the arrival of the ancestral canoe, Mātaatua, at Takou Bay.

The first "moment" I want to examine is the organisation of a game. When the children arrived on the first morning, Wally and Nora, kaumatua and kuia for the workshop and grandparents to many of the children involved, told the story of the two brothers Puhi and Toroa, their initial settlement in the Bay of Plenty and Puhi's bringing of the waka to the Bay of Islands. The children listened attentively, but with that slight clouding of the eyes that suggests the story was washing over them. If we were to elicit images and improvisations, we needed to better anchor the key points in the story. I decided to begin with the two names. A quick flick through my mental resource file threw up a tag game with a blindfolded tag pair in a circle formed by the other participants. I changed the designation of the inside pair to Puhi and Toroa and set up a soundscape of waves at the circumference.

Behind this quick decision lay an array of different categories of knowledge. In the first place there were the key fields of knowledge that a facilitator would need to undertake the workshop: of drama 
forms and processes, of history, of tikanga and te reo, of learning and teaching strategies, of developmental stages, of facilitative strategies.

During the work I had to develop further knowledges and understandings. I came knowing the story of Mātaatua, but I had learned it from Tuhoe, whose descent from Mātaatua waka came from Toroa. Here in Takou Bay, Puhi was the point of reference. This meant that the conflict in the Bay of Plenty was told from his side and the subsequent journey northward and the naming of places were the key material of the narrative. At the same time Wally and Nora stressed the importance of the genealogical ties with Tuhoe, and the importance of making the story inclusive rather than oppositional. I also had to ensure the story would be accessible for the participants. A seemingly spontaneous decision to play a simple game was grounded in an array of knowledges and strategic skills, that came from published literature, oral legacies of knowledge and practice, and a range of distilled previous experiences. Figure 2 shows some of the interplays.

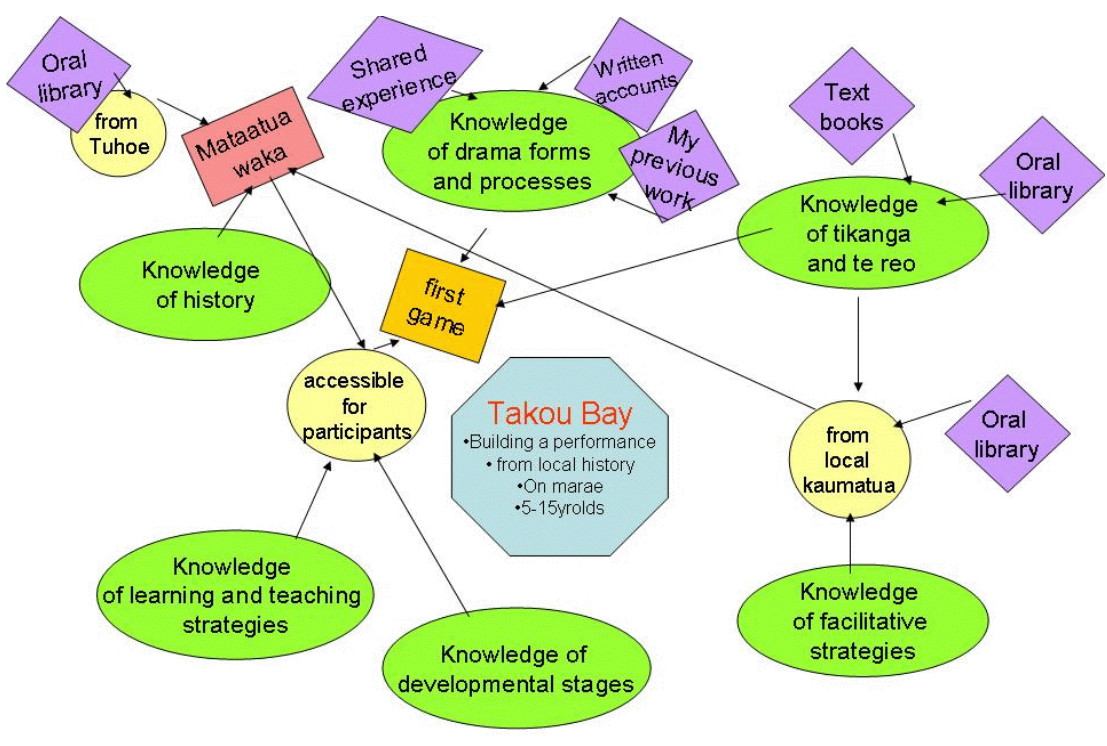

Figure 2 The fields of knowledge that informed the first game

The second "moment" is the point where we devised a haka. At one level it was a given that there would be a haka in our performance. Nevertheless it had to be a haka that would satisfy the children, the elders, and the wider community, most of whom were whanau. The participants had already devised a quantity of material and we could see that most of it could be built into the performance piece. Much of it was in English as this was the language the children came with. The haka would allow a strong strand of Māori language and would emphasise the key themes. After dinner Nora and Wally tossed around ideas. It was my task as facilitator to pick up what they were saying and at a certain point to offer the main ideas back to them. "This is what I'm hearing," I said as I wrote the words that kept recurring. "Is this our haka?" Later we passed the haka over to the participants and a group of parents to practice. Again the six groups of knowledge identified in the previous figure were drawn on.

In addition, as a Pakeha facilitator working in a Māori context, I was conscious of a complex background debate. Some of that debate takes place in the academic literature. For example, in the New Zealand context, Smith (1999), Bishop \& Glynn (1999), Te Aika \& Greenwood (2002) problematise the kind of engagement I was embarking on, talking about both the dangers of appropriation and the responsibility of Pakeha for supporting structural change. In the international arena Spivak (1996) talks about the differences between what is valued at the "centre" and at the "margins" and the importance of those who are able to move between the two "narrating a displacement". Fine (1994) examines the value of "working the hyphen" between the "self" and the "other". In my own academic writing (Greenwood, 1999, 2005; Greenwood \& Wilson, 2004, 2006), I have explored the concept of the "third space", an emergent space of possibility that develops as Māori and Pakeha cultures meet.

Alongside this literature there is a platform of lived experiences. It includes times when I've been told I should "butt out", that it is not my role to speak Māori or to have opinions on Māori issues. It includes times when I've been told it is important for me to engage, that I've been offered opportunities to learn the language so that I would use it, that a cultural partnership demands that I take an active as well as a responsive role. I hear my critics and my mentors debating behind my shoulder. Among their voices I hear the invitation that brought me into the workshop.

I evaluate my authorisation as a teacher within this situation. Here neither my registration not my record of academic publications serve to legitimise what I am doing. Some of my authorisation comes from the kuia and kaumatua who stand beside me. I assess who Nora and Wally 
are in terms of this community, and how they are regarded within it. This assessment draws on what I learn from their reputation and from current demonstration. It also aligns against my prior knowledge of the goals we are working for. Perhaps another aspect of my authorisation comes from other connections I have with this particular place, physically and spiritually. I assess the ways I should draw on them.

Not all the fields of knowledge are accessed consciously, nor are all the connections and evaluations made consciously. Nevertheless, all these components are part of the platform of scholarship that I actively draw on as I make apparently simple and apparently spontaneous decisions about what to do next.

\section{What Kind of Scholarship is Involved?}

Though small moments, these examples highlight the range of kinds of scholarship that underpin teaching decisions. There is knowledge acquired from published theory, research and accounts of practice. There is knowledge acquired from oral libraries and from shared practice. There is knowledge that comes from refinement of previous experience. The knowledge comes from multiple disciplines and use of it involves integration of learning from those disciplines.

The integration is craft based: it is interdependent with practice. It is shaped by interactions of teaching. It involves minute successive discoveries, evaluations, decisions. It is often characterised by co-discovery. As it builds on existing knowledge, it also engages in the formulation of new knowledge, for further sharing.

\section{Scholarship, Research, the PBRF, and Power}

The current environment of performance-based research funding prioritises research that leads to published outcomes. Yet in the field of education, innovation and influence often comes through the practice of outstanding teachers. My argument here is for recognition of the value of the expertise and the scholarly activity of teacher educators.

In ASTE's pre-merger negotiations with the University, affirmation of the scholarship of teaching was significant. It has continuing significance in terms of University systems of promotion, PBRF committees' assessment of portfolios, and the institutional priorities and consequent funding that are shaped by PBRF decisions.

The risks of not recognising the value are big. They come in the form of loss of time available to develop practice-based scholarliness in student teachers, in loss of courses focusing on practice-based scholarliness, in loss of retention of experienced and skilful teacher educators, in a diminution of quality in our teacher graduates. The risks extend to a threat to the quality of teaching in our schools and to the well-being of our young people.

\section{In Conclusion}

The process of merger clearly changes power relations at the institutional level. It also impacts on the way members of a merging institution view their status, or mana, and their potency to operate effectively. For teacher educators, understandings of scholarship are often at the heart of their concerns about status and power, but such understandings vary considerably. This paper has highlighted four different ways of looking at the interactions of mana, power and scholarship, and how they are affected by merger.

Institutions which are subject to major restructuring or change often focus on what they call "high level" planning - that which concerns government policy, financial viability and overarching structure. We have indicated that there is also important planning and strategising carried out at the practical operational level by those who have invested their own work into the institution's goals and who claim a say in the direction of change. We argue that all these levels of planning, conceptualising and strategising are very important to the way we creatively address complex social change.

\section{Note}

1. Acknowledgement: The research discussed here is based on work carried out at New Beginnings Preschool within the Ministry of Educations's contract funding of the Early Childhood Centres of Innovation research programme.

\section{References}

Alcorn, N. (2002). Tertiary education in New Zealand: Issues and dilemmas. New Zealand Journal of Educational Leadership, 17, 83-87.

Anderson, A. (1998). The welcome of strangers. Otago University Press, New Zealand.

Association of Staff in Tertiary Education (ASTE). (2005). Teacher education manifestation. Paper presented at Teacher Education Forum, Wellington. 
Bishop, R., \& Glynn, T. (1999). Culture counts: Changing power relations in education. Palmerston North: Dunmore Press.

Boyer, E. L. (1990). Scholarship reconsidered: Priorities of the professoriate. Princeton, NJ: Carnegie Foundation.

Burr, V. (1996). An introduction to social constructionism. London: Routledge.

Canterbury Tertiary Alliance. < http://www.cta.ac.nz>

Carr, M., May, H., \& Podmore, V. (2000). Learning and teaching stories: Action research on evaluation in early childhood. Wellington: New Zealand Council for Educational Research.

Carson, T. R., \& Sumara, D. (Eds.). (1997). Action research as living practice. New York: Peter Lang.

Castellano, M. (2000). Aboriginal education: Fulfilling the promise. Vancouver : University of British Columbia Press.

Davis, B., Sumara, D., \& Luce-Kapler, R. (2000). Engaging minds: Learning and teaching in a complex world. Mahwah, NJ: Lawrence Erlbaum Associates.

Evison, H. C. (1993). Te Waipounamu, the Greenstone Island. Christchurch: Aoraki Press.

Fine, M. (1994). Working the hyphens: Reinventing Self and Other in qualitative research. In N. K. Denzin \& Y.S. Lincoln (Eds.), Handbook of Qualitative Research (pp. 70-82). Thousand Oaks: Sage Publications.

Fletcher, W. J. (2006). The end of a chapter, the Christchurch College of Education 2000-2006. Christchurch, NZ: Christchurch College of Education/University of Canterbury School of Education.

Garmston, R., \& Wellman, B. (1999). The adaptive school: A sourcebook for developing collaborative groups. Norwood, MA: Christopher-Gordon Publishers, Inc.

Gilbert, J., \& Cameron, M. (2002). When two cultures collide: Differences between tertiary teachers in two institutional contexts. New Zealand Journal of Educational Studies, 37, 87-91.

Gilbert, J. (2005). Catching the knowledge wave? The knowledge society and the future of education. Wellington: New Zealand Council for Educational Research.

Greenwood, J. \& Wilson, A. (2006). Te Mauri Pakeaka: A journey into the third space. Auckland: Auckland University Press.
Greenwood, J. (1999). Journeys into a third space: A study of how theatre enables us to interpret the emergent space between cultures. Unpublished $\mathrm{PhD}$ thesis, Griffith University, Brisbane.<www4.gu.edu.au:8080/ adt-root/public/adt-QGU20030226.091144/index.html>

Greenwood, J. (2005). Journey into a third space: An account of how theatre can be used to interpret the emergent space between cultures. Youth Theatre Journal (USA), 19, 1-16.

Greenwood, J. (2006). Mātaatua came to Takou: Report of a community project. Presented at Drama New Zealand Conference, Taupo.

Helgesen, S. (1996). Leading from the grass roots. In F. Hesselbein, M. Goldsmith, \& R. Beckhard (Eds.), The leader of the future: New visions, strategies, and practices for the next era (pp. 19-24). San Francisco: Jossey-Bass Publishers.

hooks, bell. (1994). Teaching to transgress: Education as the practice of freedom. New York: Routledge.

Johnson, S. (2001). Emergence: The connected lives of ants, brains, cities and software. New York: Scribner.

Kvale, S. (1996). Themes of postmodernity. In W. T. Anderson (Ed.), The Fontana post modernism reader (pp. 18-25). London: Fontana Press.

Lakoff, G., \& Johnson, M. (1980). Metaphors We Live By. Chicago: The University of Chicago Press.

Lechte, J. Fifty key contemporary concepts: From abjection to Zeno's paradox. London: Sage.

Mayo, H. E. (2003). Toward collective praxis in teacher education: Complexity, pragmatism and practice. Unpublished PhD thesis, University of Canterbury, Christchurch.

Mead, H. M., \& Grove N. (2001). Ngā Pepeha ā Ngāa Tīpuna: The Sayings of the Ancestors. Wellington: Victoria University Press.

Rescher, N. (1998). Complexity: A philosophical overview. New Brunswick: Transaction Publishers.

Royal, C. (1992). Te Haurapa: An introduction to researching tribal histories and traditions. Wellington: Bridget Williams Books and Historical Branch, Department of Internal Affairs.

Schalager, M. S., \& Fusco, J. (2003). Teacher professional development, technology and communities of practice: Are we putting the cart before the horse? The Information Society, 19, 203-220. 
Schön, D. A. (1983). The reflective practitioner: How professionals think in action. New York: Basic Books.

Schrag, C. O. (1997). The self after postmodernity. New Haven: Yale University Press.

Sefa Dei G., Hall B. L., \& Rosenberg M. (2000). Teaching from the third space: Indigenous thought and local knowledge. Toronto: University of Toronto Press.

Sharp, R. (2007). Speech at Pōwhiri Whakatūhonohono, February 9, Ilam Fields, Christchurch.

Skyttner, L. (1996). General systems theory: An introduction. Basingstoke: MacMillan Press.

Smith, L. (1999). Decolonizing methodologies: Research and indigenous peoples. Dunedin: University of Otago Press.

Spivak, G. (1979). Exploration and culture: Marginalia. In Landry \& MacLean (Eds.) (1996). The Spivak Reader (pp. 29-47). New York: Routledge.

Stronach, I., \& MacLure, M. (1997). Educational research undone: The postmodern embrace. Buckingham: Open University Press.

Tau, T. M. (2003). Ngā Pikituroa o Ngāi Tahu - The oral traditions of Ngāa Tahu. Dunedin: University of Otago Press.

Te Aika, L., Greenwood, J., \& Brown, L. (2003). Report from the Christchurch College of Education Māori Bicultural Issues Committee to the Strategic Leadership Group. Christchurch.

Te Aika, L-H. \& Greenwood, J. (2002). Talking Māori; Talking bicultural. Paper presented at TEFANZ Conference, Wellington.

Thrupp, M. (1999). (Ed.) A decade of reform in New Zealand education: Where to now? Hamilton: Waikato University, School of Education.

University of Canterbury. (2006). University of Canterbury and Christchurch College of Education : Proposed merger business case. Christchurch.

Wheatley, M. J. (1999). Leadership and the new science : Discovering order in a chaotic world. (2nd ed.). San Francisco: Berrett-Koehler Publishers.

Wilson, A., \& Greenwood, J. (2004). Shifting the Centre. Perspectives in Education, 22(1), 141-148.
Wright, J., Ryder, D., \& Mayo, E. (2006). New Beginnings Preschool Centre of Innovation (May 2003-June 2006) final research report. Christchurch: New Beginnings Preschool.

\section{The authors}

Associate Professor Janinka Greenwood is currently Project Manager Research in the new University of Canterbury College of Education, with the task of facilitating the development of research that draws on practitioner-based research as well as meeting the demands of the PBRF. Dr Elaine Mayo teaches research methodology and supervises postgraduate students. She has research interests in complexity theory and in collaborative and practitioner-based research.

Lynne Hārata Te Aika is Head of School and Kaiwhakahaere Māori, with strong research interests in language revitalisation and iwi educational development.

Lawrence Walker has recently passed on his role as co-chair of ASTE and is developing his research interest in Special Needs education. 